\title{
SOME CHEMICAL CHARACTERISTICS OF THE RIVER PRA ESTUARY IN THE WESTERN REGION OF GHANA
}

\author{
J.K. Tufuor, D.K. Dodoo , A.K. Armah, G.A. Darpaah and D.K. Essumang* \\ Environmental Research Group, Department of Chemistry, University of Cape Coast, Cape \\ Coast, Ghana
}

(Received September 26, 2006; May 19, 2007)

\begin{abstract}
This paper discusses the nutrients budget and transfers of mineral nutrients from land to the sea that influence significantly the biogeochemical process operating in the coastal ecosystem. Water samples were collected fortnightly from six sites in the estuary and analysed using standard methods of analyses. It was observed that the estuary is alkaline in nature and the alkalinity increases, in the lower reach of the river as it flowed into the sea. The estuary could be classified as a well-mixed estuary due to the vertical homogenous distribution of salinity. The inorganic nitrogen in the water body exists predominately in the form of nitrate $\left(\mathrm{NO}_{3}{ }^{-}\right)$, as compared to concentrations of ammonium $\left(\mathrm{NH}_{4}{ }^{+}\right)$and nitrite $\left(\mathrm{NO}_{2}{ }^{-}\right)$. The ranges of $\mathrm{NO}_{3}{ }^{-}, \mathrm{NH}_{4}{ }^{+}$and $\mathrm{NO}_{2}{ }^{-}$concentrations are (4.98-8.27), (0.11-0.46) and (0.005-10.95) x $10^{-3} \mathrm{mg} / \mathrm{L}$. The concentrations of nitrate, nitrite, ammonium and phosphate were found to be within WHO specification. The calculated residual flow $\left(\mathrm{V}_{\mathrm{R}}\right)$ for both November and December are $-2.7 \times 10^{7} \mathrm{~m}^{3}$ day $^{-1}$ and $-1.01 \times 10^{7} \mathrm{~m}^{3}$ day ${ }^{-1}$, respectively. The negative value of $V_{R}$ implies that water flows from the system. The corresponding residence and flush times are 324 and 109 seconds and 828 and 595.2 seconds for November and December, respectively.
\end{abstract}

\section{INTRODUCTION}

The world's estuaries have been receptacles of various forms of land discharges. The situation in Ghana is not different. The Pra River has the fundamental responsibility of carrying untreated sewage, effluents from mining companies and fertilizers as a result of farming along its banks into the ocean. This observation triggered the need for investigating the chemical characteristics of the Pra River.

Area of study. The area of study is located at $5^{\circ} \mathrm{N}, 1^{\circ} 35^{\prime}-1^{\circ} 40^{\prime} \mathrm{W}$. The area happens to be the second largest discharge of fresh water into the Gulf of Guinea from Ghana. The flow water has a double maximum as a result of the rainfall pattern at the catchment's area (Table 1). The bay curves an average of $2.5 \mathrm{~km}^{2}$ with average depth of $1.5 \mathrm{~m}$, hence volume of system is $3.75 \times 10^{6}$ $\mathrm{m}^{3}$.

The river takes its source from the Kwahu plateau in the eastern region of Ghana and as it flows it joint by River Offin from Dunkwa, before it gradually empties into the Atlantic Ocean at Shama in the western region. Some major activities along the banks of the river are: (i) intensive farming along the banks in the interland (the main crops produced are plantain, banana, kolanut and cocoa); (ii) wood processing industries at Kade, Dunkwa and Daboase; and (iii) gold mining at Dunkwa, Obuasi, Konogo and diamond mines at Kade and Akwatia, which discharge their effluents into the river.

Also, the river is used by inhabitants as means of transporting their goods to and from on the market days as well as for the fishing.

Importance of the coastal zone. The coastal zone occupies only $8 \%$ of the planet's surface, but it accounts for approximately one fifth of total global primary production. Although only 5 to 10 $\%$ of the world food production is based on marine resources, as much as $85-90 \%$ of present world fisheries production comes from waters of the exclusive economic zones. Developing countries derive between 40 and $90 \%$ of their dietary proteins from marine source. Much of the

*Corresponding author. E-mail: kofiessumang@yahoo.com 
world's productive agricultural land is found in low lying costal areas in the flood plains of major rivers.

It is therefore not surprising that coastal areas have always been favoured location for human habitation and at present, estimates suggest that about $60 \%$ of the world's production live within 60 kilometres of the shoreline [2]. Estuaries are uniquely sensitive to change arising from both land and the sea. By acting as trap, they filter contaminant of sediments and act as buffer between land and the coastal zone. The importance of estuaries as fish breeding areas has been classically associated to their utilization by spawning individuals or by those that complete their cycles there or carry out migratory movements [3].

Taking into cognisance the immense contribution of the coastal zone's to mankind that is, provision of habitat, protein, minerals and fertile land for farming, it is therefore imperative to keep constant surveillance on the potential outlets of pollutants, such as estuary. With such a situation the River Pra estuary is a typical example.

The problem of eutrophication at the estuary is becoming a problem hence the need to monitor the levels of dissolved nitrogen and phosphorus which also creates health problems (methomoglobinemia) for the people who use the water.

Table 1. Mean monthly discharge $\mathrm{m}^{3} / \mathrm{s}$ of major Ghanaian rivers from 1967 - 1996 [1].

\begin{tabular}{|l|c|c|c|}
\hline Monthly & Volta & Pra & Ankobra \\
\hline January & 778.3 & 94.2 & 5.0 \\
February & 825.3 & 70.8 & 3.9 \\
March & 839.0 & 94.2 & 21.2 \\
April & 846.7 & 117.8 & 49.6 \\
May & 897.7 & 117.0 & 70.8 \\
June & 897.0 & 460.0 & 117.8 \\
July & 895.3 & 495.6 & 106.0 \\
August & 879.3 & 279.0 & 28.3 \\
September & 850.0 & 247.8 & 49.3 \\
October & 828.7 & 424.8 & 94.2 \\
November & 858.7 & 318.6 & 18.6 \\
December & 850.0 & 117.0 & 10.6 \\
\hline
\end{tabular}

Nitrate in drinking water. Nitrate in drinking water is of great concern because of its toxicity especially towards young children. The nitrate ion easily combines with hemoglobin in the body. The resulting complex between hemoglobin and nitrate ion is called methemoglobin; the association constant for methemoglobin formation is larger than that for oxyhemoglobin formation, and so the nitrate ions ties up the hemoglobin, depriving the tissues of oxygen. Severe cases of methemoglolobinemia can result in mental retardation in the infant. Also the nitrate ion in the stomach is capable of nitrating secondary amides and secondary amines. The resulting $\mathrm{N}$-nitrosamines may be carcinogenic. This has been found to be true in many animal species, although it is not a confirmed human carcinogen [4].

\section{EXPERIMENTAL}

A water sampler was designed in our laboratory which could collect simultaneously two samples from a site at different depths. Six sites were chosen along the bay (Figure 1) and samples were collected using a boat at different depths (surface - $1.2 \mathrm{~m}$ from the river bed, and bottom $-0.2 \mathrm{~m}$ from the river bed) with the aid of the sampler containing cleaned air-dried 1.5 litre plastic bottles. The samples were then put in an ice chest and shipped to the laboratory where $5 \mathrm{~mL}$ of chloroform were added to each and stored at $4{ }^{\circ} \mathrm{C}$ until analyses. Samples were collected fortnightly. 
The parameters analysed were $\mathrm{pH}$, salinity, alkalinity $\left(\mathrm{HCO}_{3}{ }^{-}\right)$, nitrate-nitrogen, ammonianitrogen, nitrite-nitrogen, orthophosphate-phosphorus, and dissolved organic carbon.
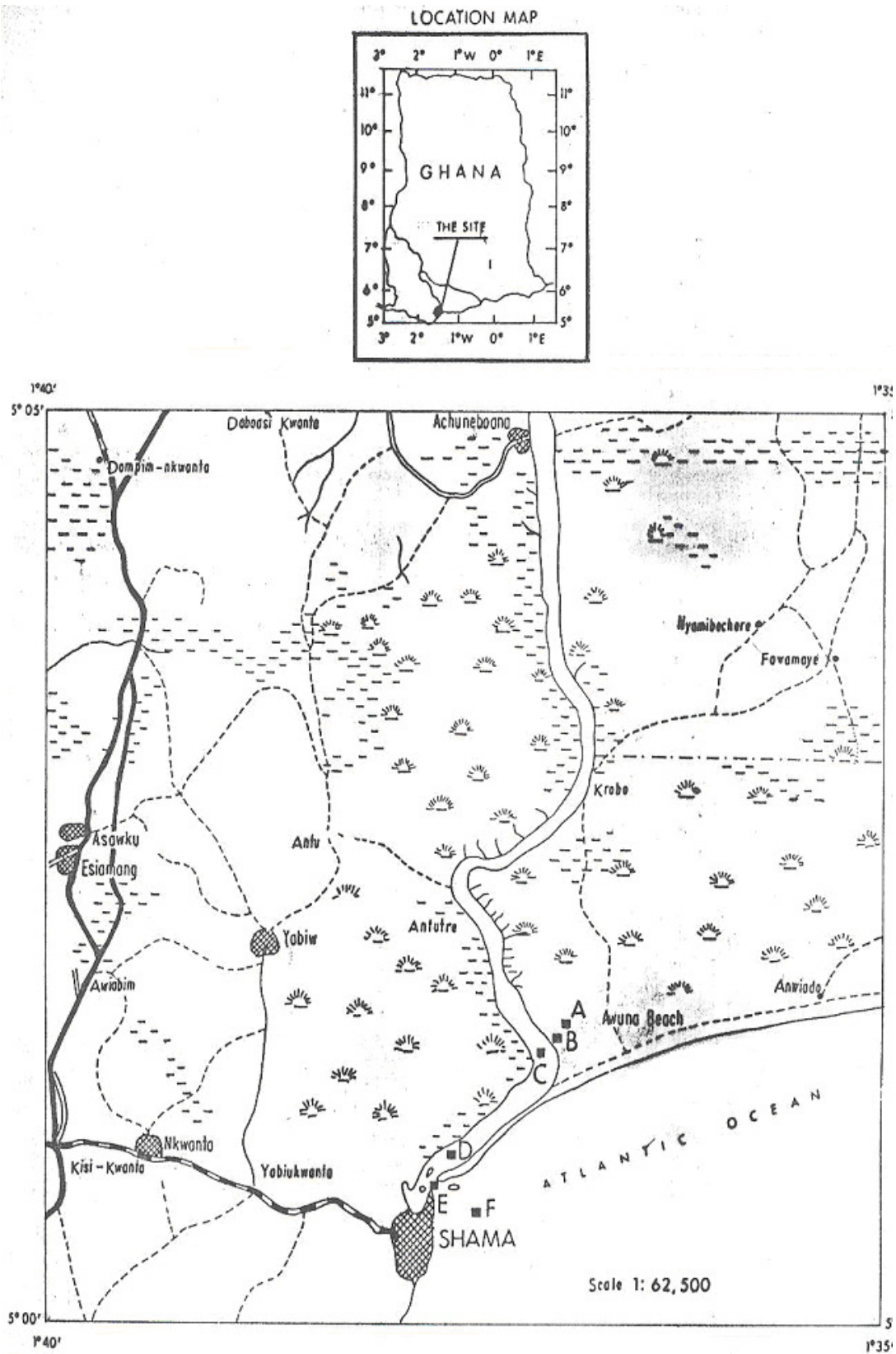

Figure 1. Map of the River Pra Estuary showing sampling sites A, B, C, D, E and F in the study area. 
344 Some chemical characteristics of the River Pra Estuary in Western region of Ghana

Standard models used in computing water and salts budgets are illustrated below.

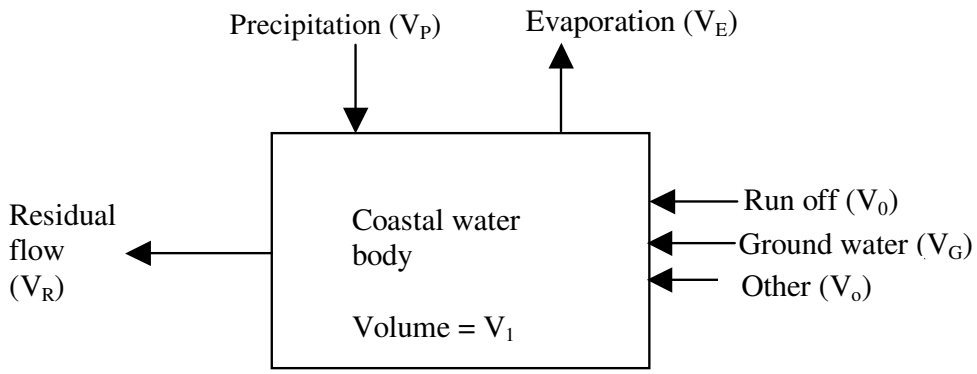

Figure 2. Generalised diagram illustrating the budget for water [5]. The model is based on the concept that water is conserved.

The water in storage is represented by the equation.

$\mathrm{dVi} / \mathrm{dt}=\mathrm{V}_{\mathrm{Q}}+\mathrm{V}_{\mathrm{p}}+\mathrm{V}_{\mathrm{G}}+\mathrm{V}_{\mathrm{O}}+\mathrm{V}_{\text {in }}-\mathrm{V}_{\mathrm{E}}-\mathrm{V}_{\text {out }}$

where $\mathrm{V}_{\mathrm{p}}$ = direct precipitation, $\mathrm{V}_{\mathrm{G}}=$ ground water, $\mathrm{V}_{\mathrm{O}}=$ other inflows such as sewage, $\mathrm{V}_{\text {in }}=$ hydrographically driven advective inflow, $\mathrm{V}_{\mathrm{E}}=$ evaporation, $\mathrm{V}_{\mathrm{out}}=$ advective outflow of water from the system, $\mathrm{V}_{\mathrm{Q}}=$ stream runoff.

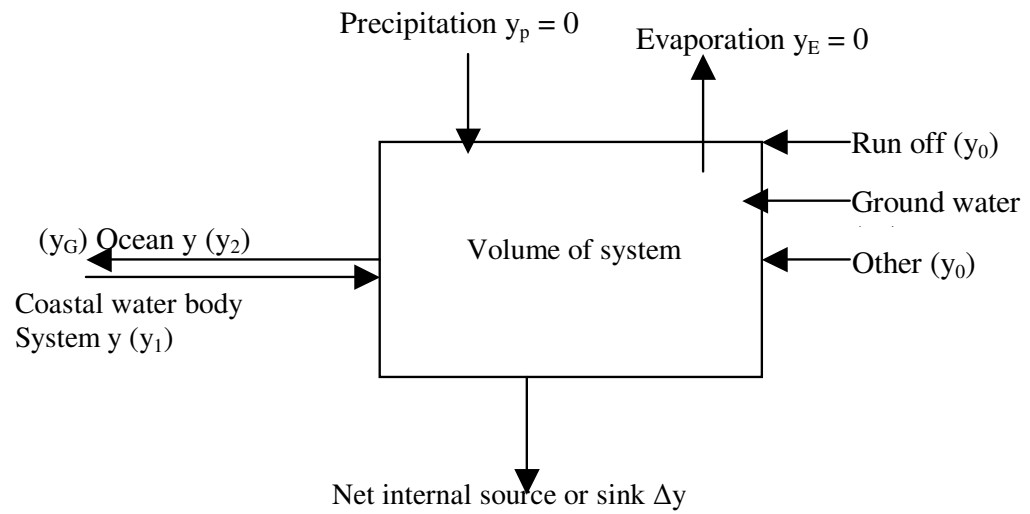

Figure 3. Generalized diagram illustrating the budget for a non-conservative material, $\mathrm{y}\left(\mathrm{NO}_{3}{ }^{-}\right.$, $\left.\mathrm{PO}_{4}{ }^{2-}\right)$.

The general equation for calculating the salt balance is given by the expression

$\Delta \mathrm{Y}=\mathrm{V}_{\mathrm{R}} \mathrm{Y}_{\mathrm{R}}-\mathrm{V}_{\mathrm{X}}\left(\mathrm{Y}_{2}-\mathrm{Y}_{1}\right)$

and $\mathrm{V}_{\mathrm{X}}=\mathrm{V}_{\mathrm{R}} \mathrm{S}_{\mathrm{R}} /\left(\mathrm{S}_{2}-\mathrm{S}_{1}\right)$

where $S_{R}=$ average of $S_{1}$ and $S_{2}$ and all others are defined in Figures 2 and 3 and also in Table 5 . 


\section{RESULTS AND DISCUSSION}

$p H$. From Table 2 and 3 it could be seen that the $\mathrm{pH}$ for all the sites ranged from slightly neutral to moderately alkaline (7.77-8.53). This range of $\mathrm{pH}$ provides the best condition for ammonium oxidation. This is seen in the figures where literally all the $\mathrm{NH}_{4}{ }^{+}$is oxidized to $\mathrm{NO}_{3}{ }^{-}$.

The population of autotrophic ammonium oxidizing organism is greater in neutral and alkaline soils. Autotrophic ammonia-oxidizing bacteria in liquid culture are optimal within the $\mathrm{pH}$ range 7.0-8.5 and typically do not occur at $\mathrm{pH}$ of 6.5 [6]. It can be inferred from Table 2 and 3 that the water body is in the alkaline medium and this increase in the lower reach of the estuary.

Table 2. Average of analysis in November 1999.

\begin{tabular}{|l|l|l|l|l|l|l|l|l|l|}
\hline Site & $\mathrm{pH}$ & $\begin{array}{l}\mathrm{Salinity} \\
0 / 00\end{array}$ & $\begin{array}{l}\mathrm{mg} \\
\mathrm{NO}^{-3} / \mathrm{L}\end{array}$ & $\begin{array}{l}\mu \mathrm{g} \\
\mathrm{NO}_{2} / \mathrm{L}\end{array}$ & $\begin{array}{l}\mathrm{mg} \\
\mathrm{NH}_{4}{ }^{+} / \mathrm{L}\end{array}$ & $\begin{array}{l}\mathrm{mg} \\
\mathrm{PO}_{4}{ }^{3-} / \mathrm{L}\end{array}$ & $\begin{array}{l}\mathrm{mg} \\
\mathrm{DOC} / \mathrm{L}\end{array}$ & $\begin{array}{l}\mathrm{mg} \\
\mathrm{CO}_{3}{ }^{2} / \mathrm{L}\end{array}$ & $\begin{array}{l}\mathrm{mg} \\
\mathrm{HCO}_{3}{ }^{-} / \mathrm{L}\end{array}$ \\
\hline $\mathrm{A}_{1}$ & $7.95 \pm 0.01$ & $1.27 \pm 0.01$ & $23.41 \pm 0.1$ & $0.51 \pm 0.03$ & $0.150 \pm 0.1$ & $3.30 \pm 0.1$ & $813 \pm 0.3$ & - & $120.8 \pm 0.4$ \\
$\mathrm{~A}_{2}$ & $7.90 \pm 0.01$ & $0.78 \pm 0.01$ & $23.40 \pm 0.1$ & $0.56 \pm 0.03$ & $0.360 \pm 0.1$ & $3.95 \pm 0.1$ & $909 \pm 0.3$ & - & $131.9 \pm 0.4$ \\
$\mathrm{~B}_{1}$ & $7.90 \pm 0.02$ & $0.16 \pm 0.01$ & $18.70 \pm 0.1$ & $0.51 \pm 0.04$ & $0.201 \pm 0.1$ & $1.51 \pm 0.2$ & $805.5 \pm 0.3$ & - & $110.7 \pm 0.3$ \\
$\mathrm{~B}_{2}$ & $7.90 \pm 0.01$ & $0.10 \pm 0.01$ & $14.80 \pm 0.1$ & $0.48 \pm 0.04$ & $0.210 \pm 0.1$ & $1.61 \pm 0.2$ & $749 \pm 0.4$ & - & $114.2 \pm 0.3$ \\
$\mathrm{C}_{1}$ & $7.95 \pm 0.01$ & $0.01 \pm 0.01$ & $9.11 \pm 0.1$ & $2.64 \pm 0.02$ & $0.267 \pm 0.1$ & $0.77 \pm 0.2$ & $485.1 \pm 0.3$ & - & $90.2 \pm 0.4$ \\
$\mathrm{C}_{2}$ & $8.15 \pm 0.03$ & $0.01 \pm 0.01$ & $8.27 \pm 0.1$ & $3.95 \pm 0.01$ & $0.152 \pm 0.2$ & $0.72 \pm 0.2$ & $370 \pm 0.3$ & - & $89.0 \pm 0.4$ \\
$\mathrm{D}_{1}$ & $8.30 \pm 0.01$ & $0.60 \pm 0.01$ & $14.14 \pm 0.1$ & $5.51 \pm 0.03$ & $0.150 \pm 0.2$ & $0.78 \pm 0.2$ & $991 \pm 0.4$ & - & $88.4 \pm 0.3$ \\
$\mathrm{D}_{2}$ & $8.10 \pm 0.03$ & $0.60 \pm 0.01$ & $12.00 \pm 0.1$ & $7.38 \pm 0.01$ & $0.258 \pm 0.2$ & $1.63 \pm 0.1$ & $1156 \pm 0.4$ & - & $82.4 \pm 0.3$ \\
$\mathrm{E}_{1}$ & $8.30 \pm 0.01$ & $1.66 \pm 0.01$ & $33.85 \pm 0.1$ & $9.88 \pm 0.03$ & $0.260 \pm 0.2$ & $0.64 \pm 0.1$ & $661 \pm 0.3$ & - & $85.5 \pm 0.4$ \\
$\mathrm{E}_{2}$ & $8.50 \pm 0.01$ & $1.42 \pm 0.01$ & $17.46 \pm 0.1$ & $13.78 \pm 0.03$ & $0.286 \pm 0.2$ & $0.63 \pm 0.2$ & $661 \pm 0.3$ & - & $91.0 \pm 0.4$ \\
$\mathrm{~F}_{1}$ & $8.40 \pm 0.01$ & $14.37 \pm 0.01$ & $24.54 \pm 0.2$ & $6.21 \pm 0.02$ & $0.298 \pm 0.2$ & $0.36 \pm 0.2$ & $330 \pm 0.3$ & 18 & $128.1 \pm 0.3$ \\
$\mathrm{~F}_{2}$ & $8.50 \pm 0.01$ & $13.96 \pm 0.01$ & $17.46 \pm 0.2$ & $10.95 \pm 0.02$ & $0.460 \pm 0.2$ & $0.032 \pm 0.2$ & $110 \pm 0.3$ & 18 & $143.4 \pm 0.3$ \\
\hline
\end{tabular}

Site: 1- Represents water collected from surface. 2 - Represents water collected from bottom.

Table 3. Average of analyses in December 1999.

\begin{tabular}{|l|l|l|l|l|l|l|l|l|l|}
\hline Site & $\mathrm{pH}$ & $\begin{array}{l}\text { Salinity } \\
0 / 00\end{array}$ & $\mathrm{mg} \mathrm{NO}{ }^{-3} / \mathrm{L}$ & $\mu \mathrm{g} \mathrm{NO}{ }_{2} / \mathrm{L}$ & $\begin{array}{l}\mathrm{mg} \\
\mathrm{NH}_{4}{ }^{+} / \mathrm{L}\end{array}$ & $\begin{array}{l}\mathrm{mg} \\
/ \mathrm{L}\end{array} \mathrm{PO}_{4}{ }^{3-}$ & $\begin{array}{l}\mathrm{mg} \\
\mathrm{DOC} / \mathrm{L}\end{array}$ & $\begin{array}{l}\mathrm{mg} \\
\mathrm{CO}_{3}{ }^{2-} / \mathrm{L}\end{array}$ & $\begin{array}{l}\mathrm{mg} \\
/ \mathrm{L}\end{array}$ \\
\hline $\mathrm{A}_{1}$ & $7.81 \pm 0.01$ & $6.08 \pm 0.01$ & $24.44 \pm 0.1$ & $0.005 \pm 0.02$ & $0.23 \pm 0.1$ & $0.711 \pm 0.1$ & $968 \pm 0.3$ & - & $125.6 \pm 0.4$ \\
$\mathrm{~A}_{2}$ & $7.77 \pm 0.01$ & $5.77 \pm 0.02$ & $33.14 \pm 0.1$ & $0.01 \pm 0.03$ & $0.25 \pm 0.1$ & $0.621 \pm 0.2$ & $904 \pm 0.3$ & - & $126.9 \pm 0.3$ \\
$\mathrm{~B}_{1}$ & $7.99 \pm 0.01$ & $3.42 \pm 0.02$ & $26.34 \pm 0.1$ & $0.01 \pm 0.02$ & $0.10 \pm 0.1$ & $0.331 \pm 0.2$ & $769 \pm 0.4$ & - & $98.8 \pm 0.3$ \\
$\mathrm{~B}_{2}$ & $7.88 \pm 0.01$ & $2.37 \pm 0.01$ & $13.89 \pm 0.1$ & $0.011 \pm 0.02$ & $0.13 \pm 0.2$ & $0.331 \pm 0.1$ & $827 \pm 0.3$ & - & $99.6 \pm 0.4$ \\
$\mathrm{C}_{1}$ & $8.00 \pm 0.01$ & $1.21 \pm 0.01$ & $14.89 \pm 0.2$ & $0.04 \pm 0.03$ & $0.20 \pm 0.2$ & $0.027 \pm 0.1$ & $926 \pm 0.3$ & - & $85.7 \pm 0.4$ \\
$\mathrm{C}_{2}$ & $8.00 \pm 0.01$ & $1.29 \pm 0.01$ & $12.90 \pm 0.2$ & $0.035 \pm 0.02$ & $0.21 \pm 0.1$ & $0.021 \pm 0.2$ & $598 \pm 0.2$ & - & $86.8 \pm 0.3$ \\
$\mathrm{D}_{1}$ & $8.21 \pm 0.01$ & $5.44 \pm 0.02$ & $20.72 \pm 0.2$ & $0.026 \pm 0.02$ & $0.21 \pm 0.1$ & $0.52 \pm 0.2$ & $896 \pm 0.3$ & - & $128.8 \pm 0.3$ \\
$\mathrm{D}_{2}$ & $8.05 \pm 0.01$ & $4.00 \pm 0.02$ & $22.93 \pm 0.2$ & $3.83 \pm 0.02$ & $0.22 \pm 0.1$ & $0.33 \pm 0.2$ & $431 \pm 0.3$ & - & $118.3 \pm 0.4$ \\
$\mathrm{E}_{1}$ & $8.53 \pm 0.01$ & $7.00 \pm 0.02$ & $24.00 \pm 0.1$ & $0.03 \pm 0.02$ & $0.14 \pm 0.2$ & $0.058 \pm 0.2$ & $404 \pm 0.3$ & - & $138.7 \pm 0.4$ \\
$\mathrm{E}_{2}$ & $8.02 \pm 0.01$ & $10.58 \pm 0.01$ & $39.86 \pm 0.1$ & $12.42 \pm 0.02$ & $0.23 \pm 0.2$ & $0.056 \pm 0.1$ & $639 \pm 0.4$ & - & $98.8 \pm 0.3$ \\
$\mathrm{~F}_{1}$ & $8.339 \pm 0.01$ & $28.00 \pm 0.01$ & $11.08 \pm 0.1$ & $0.025 \pm 0.03$ & $0.27 \pm 0.2$ & $0.02 \pm 0.1$ & $627 \pm 0.4$ & - & $142.2 \pm 0.3$ \\
$\mathrm{~F}_{2}$ & $8.52 \pm 0.01$ & $28.18 \pm 0.01$ & $22.93 \pm 0.1$ & $3.83 \pm 0.03$ & $0.28 \pm 0.2$ & $0.52 \pm 0.1$ & $110 \pm 0.4$ & - & $141.7 \pm 0.4$ \\
\hline
\end{tabular}

Salinity. Using a saline - fresh water demarcation of $3 \%_{0}$ [7], the surface waters of the estuary of River Pra was fresh up to the point of entry into the Gulf of Guinea (Table 2). From Table 3, only sites $\mathrm{B}_{1} \mathrm{C}_{1}$ and $\mathrm{C}_{2}$ could be classified as fresh water.

Tidal pumping, which is caused by residual horizontal circulation, is an important but illunderstood mechanism of tidal flow that produces longitudinal salt dispersion.

Although in the central saline part of estuaries with a strong salinity gradient, gravitational (vertical) circulation is the most important factor for mixing and dispersion, in the sea-ward part of wider estuaries, where the density gradient is small, tidal pumping is the main mixing mechanism. In classical literature, the importance of this type of circulation is recognized, but no 
efforts have been made to quantify this mechanism in terms of a longitudinal dispersion coefficient. [8]. On this basis an estuary may be classified as salt wedge, partially mixed fjord type and well mixed or vertically homogenous. Based on the data obtained in (Table 2 and 3 ) the River Pra estuary may be classified as vertically homogenous, since the salinity of the water is uniform within a metre deep.

Plant nutrients (nitrogen and phosphorus). As it has been discussed earlier the dominant species of nitrogen in the water is in the form of $\mathrm{NO}_{3}{ }^{-}$. Drinking of River Pra (which is source of water for both human and animals) will not lead to the two cases discussed under nitrate in drinking water in introduction, since the nitrate concentration is less than accepted upper limits of 45 $\mathrm{mg} / \mathrm{L}$ for United States [9].

The $\mathrm{pH}$ range has been found to be 7.77-8.53, therefore considering the dissociation curve of phosphoric acid the bulk of the phosphate - phosphorus analysed will be in the form of $\mathrm{HPO}_{4}{ }^{2-}$.

From Table 2 and 3 the low variation in phosphorus concentration at each site may be the result of some buffering mechanism whereby phosphorus is released from or absorbed by the sediments depending on its concentration [10].

Dissolved organic carbon (DOC). In estuaries the amount of organic matter, living and dead, is usually greater than in open sea and the decomposition of organic matter in estuaries can lead to anoxic condition if the water exchange is poor or if large amounts of organic pollutants are introduced.

From Tables 2 and 3 the range for the DOC is $110-1156 \mathrm{mg} \mathrm{C} / \mathrm{L}$ with the ocean registering the lowest of $110 \mathrm{mg} \mathrm{C} / \mathrm{L}$. On the whole surface samples had higher DOC values than the bottom samples. The relatively high concentration at D2 might be due to higher micro-organism activities and oxidation, since the water appears more stagnant at the surface as compared to the bottom.

Water and salt budget. The River Pra estuary can be described as a positive estuary, because the precipitation exceeded evaporation during the period of study as shown in Table 4. Also the calculated residence time was found to be 324 seconds in November and 828 seconds in December. The considerably low residence time of the Pra estuary compared to 11 days of the Estero de Punta Banda, Baja California [11] gives it an advantage of dislodging treated effluents at a much rapid rate. It can therefore be assumed that accumulating waste and build up high concentrations of land-derived pollutants is minimal and hence this estuary could be described as healthy, productive and useful body of water.

Table 4. Fresh water inputs and composition of River Pra.

\begin{tabular}{|l|l|l|l|l|}
\hline & $\mathrm{V}\left(10^{3} \mathrm{~m}^{3}\right.$ day $^{-1}$ & $\begin{array}{l}\text { Total DIN }\left[\mathrm{NO}_{3}{ }^{-}\right]+\left[\mathrm{NO}_{3}{ }^{-}\right]+ \\
{\left[\mathrm{NH}_{4}{ }^{+}\right]}\end{array}$ & $\mathrm{DIP}$ \\
\hline Fresh water inflow $\mathrm{V}_{\mathrm{Q}}$ (Nov.) & $2.7 \times 10^{4}(\mathrm{a})$ & 0 & & 0 \\
Fresh water inflow $\mathrm{V}_{\mathrm{Q}}$ (Dec.) & $1.10 \times 104(\mathrm{a})$ & 0 & & 0 \\
Ground water $\mathrm{V}_{\mathrm{G}}$ (Nov.) & 0 & 0 & & 0 \\
Ground water $\mathrm{V}_{\mathrm{G}}$ (Dec.) & 0 & 0 & & 0 \\
Precipitation $\mathrm{V}_{\mathrm{p}}$ (Nov.) & $7.450(\mathrm{~b})$ & (assumed) 0 & & 0 \\
Precipitation $\mathrm{V}_{\mathrm{p}}$ (Dec.) & $7.525(\mathrm{~b})$ & 0 & & 0 \\
Evaporation $\mathrm{V}_{\mathrm{E}}$ (Nov.) & $-5.50(\mathrm{~b})$ & 0 & 0 \\
Evaporation $\mathrm{V}_{\mathrm{E}}$ (Dec.) & $-4.750(\mathrm{~b})$ & 0 & & 0 \\
\hline
\end{tabular}

(a) Equivalent of the mean monthly discharge of Pra River for the months of November and December.

(b) Data collected from meteorological station (Takoradi Airforce base). 
The computed non-conservative flux of phosphorus and nitrogen were $1.36308 \times 10^{7} \mathrm{~m}^{3}$ day $^{-1} \mathrm{mg} / \mathrm{L}, 8.5217 \times 10^{7} \mathrm{~m}^{3}$ day $^{-1} \mathrm{mg} / \mathrm{L}$, respectively (these values were arrived at using equations 1, 2 and 3 and substituting appropriate results in Tables 4 and 5). Their positive values indicate that there is a net "production" of both dissolved inorganic nitrogen (DIN) and dissolved inorganic phosphorus (DIP) within the system. From this observation it could be inferred that nitrogen fixation exceeds denitrification hence the estuary becomes an important source of nitrogen. The source of this nitrogen in the system can come from various other processes including physical, abiotic and biotic chemical forms. For the case of phosphate the sediments does not contribute significantly to the net phosphate, the DIP production is probably from organic matter oxidation.

Table 5. Chemical composition of River Pra for November and December 1999.

\begin{tabular}{|l|l|l|l|l|l|}
\hline Site & Salinity & $\mathrm{mg}$ DIP $/ \mathrm{L}$ & Total DIN mg/L $\left[\mathrm{NO}_{2}{ }^{-}\right]+\left[\mathrm{NO}_{2}{ }^{-}\right]+\left[\mathrm{NH}_{4}{ }^{+}\right]$ & $\mathrm{DIP}_{\mathrm{Q}}$ & $\mathrm{DIN}$ \\
\hline Ocean (Nov.) & $\mathrm{S}_{2}=14.17$ & 0.196 & 21.34 & 0.77 & 9.377 \\
Bay (Nov.) & $\mathrm{S}_{1}=0.60$ & 1.205 & 15.78 & 0.72 & 8.421 \\
Ocean (Dec.) & $\mathrm{S}_{2}=28.09$ & 0.22 & 17.77 & 0.027 & 15.09 \\
Bay (Dec.) & $\mathrm{S}_{1}=4.72$ & 0.28 & 22.05 & 0.021 & 13.11 \\
\hline
\end{tabular}

The system is susceptible to nutrient pollution, thus the input of both nitrogen and phosphorus containing substance should be limited or prevented.

\section{CONCLUSIONS}

River Pra and its tributaries, notably river Offin, are subjected to muddy effluent from gold mines at Dunkwa, Obuasi and Konongo and diamond mines at Oda, Kade and Akwatia. The effect of industry effluent on the water quality is that of transparency. Thus the River Pra is dirty in colour with low transparency.

The Pra estuary has a vertical homogenous salinity that qualifies it to be classified as a wellmixed estuary. Also the water is alkaline, with alkalinity increasing towards the ocean. The average nitrate concentration is within the United State accepted limit, therefore cases of methomoglobinemia in infants living alone the estuary might not be associated with the water body.

From the calculated change in dissolved inorganic phosphorus ( $\Delta$ DIP) and change in dissolved inorganic nitrogen $(\Delta$ DIP) for the period of research indicates that the estuary is a source of both nitrogen and phosphorus. Thus the input of both nitrogen and phosphorus containing substances should be prevented. Also the residence and flushing times of the Pra estuary are both small. This rapid flushing system could be a means of discharging treated effluents into the sea.

\section{AKNOWLEDGEMENTS}

The authors wish to thank the University of Cape Coast, Cape Coast for providing facilities for the study and Standard Chartered Bank for providing funds to support this work.

\section{REFERENCES}

1. Armah, A.K.; Amlado, D.S. Coastal Zone Profile of Ghana, Penshaw Press: Sunderland; 1998; pp. 1100-1102.

2. Pernetta, J.C.; Milliman, J.D. I.G.B.P. Global Change, Stockholm 1995; Report No. 33. pp. 99. 
348 Some chemical characteristics of the River Pra Estuary in Western region of Ghana

3. Blaber, S.J.M. Tropical Estuarine Fishes Ecology Exploitation and Conservation, Blackwell: Oxford; 2000; p 972.

4. Nigel J.B. Environmental Chemistry, 2nd ed., Wuerz Publishing Ltd: Winnepeg, Canada; 1994; pp. 222-223.

5. Webster, I.T., Parslow, J.S.; Smith, S.V. Estuaries 2000, 23, 341.

6. Allison, S.M.; Prossor, J.I. Soil Biol. Biolchem. 1993, 25, 935.

7. Lewis, E.L. J. Ocean. Eocean. Eng. (O. E.) 1980, $5,3$.

8. Nguyen, A.D.; Savenije, H.H.G.; Van der Wegen, M. Geophysical Research Abstracts, 2006, 8, 01259 .

9. Glidewell, C. Chem. Britain 1990, 26, 137.

10. Froclick, P.N. Limnol. Oceanogr. 1988, 33, 649.

11. Camacho-Ibar, V.F., Carriquiry, J.D.; Smith, S.V. in Comparison of carbon, nitrogen and phosphorus fluxes in Mexican coastal lagoons, Smith, S.V., Ibarra-Obando, S., Boudreau, P.R.; Camacho-Ibar, V.F. (Eds.), LOICZ Reports and Studies 10, LOICZ, Texel. 1997. 